\title{
Pemanfaatan Barang Milik Daerah \\ (Suatu pendekatan teoritis dan praktis dalam menentukan metode pemanfaatan aset)
}

\author{
Nunung Runiawati ${ }^{1}$
}

\begin{abstract}
Abstrak
Pemanfaatan Barang Milik Daerah (BMD) adalah pendayagunaan BMD yang tidak digunakan untuk penyelenggaraan tugas dan fungsi satuan kerja perangkat daerah dan/atau optimalisasi Barang Milik Daerah dengan tidak mengubah status kepemilikannya. Pemanfaatan BMD memberikan peluang bagi daerah untuk meningkatkan pendapatan asli daerah (PAD) serta meningkatkan fasilitas publik. Rumusan masalah dalam kajian ini adalah konsep pemanfaatan aset dalam peningkatan pendapatan asli daerah, metode pemanfaatan aset, penetapan kontribusi, dan studi kasus pemilihan metode pemanfaatan aset dalam pengembangan kawasan pariwisata pantai. Kajian ini menggunakan pendekatan teoritis dalam menjelaskan konsep dan metode pemanfaatan BMD serta menggunakan data hasil penelitian dalam membahas studi kasus pemilihan metode pemanfaatan BMD. Paper ini bertujuan memberikan gambaran dalam pemanfaatan barang milik daerah serta manfaatnya dalam peningkatan PAD. Hasil pembahasan menunjukan bahwa terdapat 5 merode pemanfaatan aset yaitu sewa, pinjam pakai, kerja sama pemanfaatan, bangun guna serah, bangun serah guna, dan kerja sama infrastruktur yang satu sama lain memiliki tujuan, keunggulan dan karakteristik tersendiri. Dalam rangka peningkatan pendapatan asli daerah, setiap metode pemanfaatan aset (kecuali pinjam pakai) memiliki bentuk kontribusinya masing-masing yang mampu meningkatkan pendapatan daerah dan/atau peningkatan aset daerah.. Pemilihan metode pemanfaatan aset hendaknya didasarkan pada visi dan misi daerah serta metode yang paling memberikan dampak rentetan terbesar terhadap pertumbuhan ekonomi daerah.
\end{abstract}

Kata Kunci : Pemanfaatan, Barang Milik Daerah, Sewa, Pinjam Pakai, Kerja Sama Pemanfaatan, Bangun Guna Serah, Bangun Serah Guna, Kerja Sama Infrastruktur

\section{Pendahuluan}

Saat ini, aset daerah atau yang dikenal sebagai barang milik daerah (BMD) tidak hanya dipandang sebagai sarana dan prasarana agar urusan pemerintah daerah dapat diwujudkan namun aset dapat dioptimalkan guna menggerakan perekonomian daerah. Melalui manajemen aset, pemerintah daerah diharapkan mampu mengoptimalkan pengelolaan aset sehingga mampu menwujudkan pembangunan yang berkelanjutan.

\footnotetext{
${ }^{1}$ Dosen Administrasi Publik Fisip Universitas Padjadjaran
}

Kesadaran pentingnya pengelolaan aset bagi pemerintah daerah semakin hari semakin meningkat seiring dengan perbaikan regulasi pengelolaan aset di tingkat pusat dan daerah, tuntutan pelaporan keuangan serta tuntutan otonomi daerah. Otonomi daerah mengharuskan suatu daerah untuk mandiri dalam melakukan pendanaan termasuk mengoptimalkan sumbersumber pendapatan asli daerah (PAD). Pemanfaatan aset memberikan peluang bagi daerah untuk meningkatkan PADnya serta meningkatkan fasilitas publik. Namun faktanya, 
banyak aset yang dimiliki oleh pemerintah daerah yang belum mampu menghasilkan keuntungan bagi daerah. Melalui mekanisme pemanfaatan aset inilah diharapkan dapat menjadi peluang bagi daerah untuk mengoptimalisasi aset yang dimiliki sehingga mampu meningkatkan PADnya.

Definisi Pemanfaatan menurut PP 27/2014

Pasal 1 adalah pendayagunaan barang milik negara/daerah yang tidak digunakan untuk penyelenggaraan tugas dan fungsi Kementerian/Lembaga/satuan kerja perangkat daerah dan/atau optimalisasi Barang Milik Negara/Daerah dengan tidak mengubah status kepemilikannya. Pemanfaatan merupakan tahapan keempat dalam pengelolaan BMD jika mengacu kepada Peraturan Pemerintah Republik Indonesia Nomor 27 Tahun 2014 tentang pengelolaan barang milik negara/daerahpasal 3 ayat (2) setelah perencanaan kebutuhan dan penganggaran, pengadaan dan penggunaan.

Rumusan masalah dalam kajian ini adalah bagaimana konsep pemanfaatan aset dalam serta metode, penetapan kontribusi, dan studi kasus dalam pemilihan metode pemanfaatan aset. Kajian ini menggunakan pendekatan teoritis dalam menjelaskan konsep, metode dan penetapan kontribusi serta menggunakan data hasil penelitian dalam membahas studi kasus pemilihan metode pemanfaatan aset. Paper ini bertujuan memberikan gambaran dalam pemanfaatan barang milik daerah serta manfaatnya dalam peningkatan PAD.

\section{Kajian Literatur}

Menurut Siregar, "aset merupakan barang (thing) atau sesuatu barang (anything) yang mempunyai nilai ekonomi, nilai komersial, atau nilai tukar yang dimiliki oleh badan usaha, instansi, atau individu (178)." Aset daerah dalam ketentuan peraturan perundangan dikenal juga sebagai Barang Milik Daerah. Berdasarkan Peraturan Pemerintah Republik Indonesia No. 27 Tahun 2014 tentang Pengelolaan Barang Milik Negara/Daerah, Barang Milik Daerah adalah semua barang yang dibeli atau diperoleh atas beban Anggaran Pendapatan dan Belanja Negara atau berasal dari perolehan lainnya yang sah.

Berdasarkan Peraturan Pemerintah Republik Indonesia Nomor 27 Tahun 2014 tentang Pengelolaan Barang Milik Negara/DaerahPasal 3 ayat (2) terdapat 11 siklus dalam pengelolaan barang diantaranya adalah:

a. Perencanaan kebutuhan dan penganggaran;

b. Pengadaan;

c. Penggunaan;

d. Pemanfaatan;

e. Pengamanan dan pemeliharaan;

f. Penilaian;

g. Pemindahtanganan;

h. Pemusnahan;

i. Penghapusan;

j. Penatausahaan; dan

k. Pembinaan, pengawasan, dan pengendalian.

Sesuai dengan ketentuan tersebut, pemanfaatan merupakan tahapan keempat dalam pengelolaan BMN/D.

Dalam skema pemanfaatan, Savas bentukbentuk pemanfaatan yang dikenal dengan the spectrum of public and private partnership. Adapun model-model privatisasi infrastruktur dikategorikan dalam 3 jenis fasilitas, yakni fasilitas yang ada, fasilitas yang membutuhkan investasi untuk ekspansi atau rehabilitasi dan fasilitas yang baru akan dibangun. Untuk jenis fasilitas yang ada, model privatisasinya dilakukan dengan dijual, sewa, dan kontrak/ perjanjian operasional dan pemeliharaan. Selanjutnya untuk fasilitas yang membutuhkan investasi untuk ekspansi atau rehabilitasi, model privatisasi adalah dengan Lease-Build-Operate (LBO) atau Buy-Build-Operate (BBO) dan wraparound addition dimana Perusahaan swasta menyewa atau membeli fasilitas dari pemerintah, beroperasi di bawah kesepakatan dan membayar biaya tertentu. Sedangkan untuk fasilitas yang akan baru dibangun, model privatisasi dengan cara Build-Transfer-Operate (BTO), BuildOperate-Transfer (BOT) dan Build Own Operate (BOO).

Apabila digambarkan the spectrum of public and private partnership adalah sebagai berikut: 
Gambar 1 The Spectrum of Public and Private Partnership

\begin{tabular}{|c|c|c|c|c|c|c|c|c|c|c|}
\hline $\begin{array}{l}\text { Governm } \\
\text { ent } \\
\text { Departe } \\
\text { ment }\end{array}$ & $\begin{array}{l}\text { Public } \\
\text { Authority }\end{array}$ & $\begin{array}{l}\text { Service } \\
\text { Contract }\end{array}$ & $\begin{array}{l}\text { Operatio } \\
\text { ns and } \\
\text { Mainten } \\
\text { ance } \\
\text { Contract }\end{array}$ & $\begin{array}{l}\text { Cooperat } \\
\text { ive }\end{array}$ & $\begin{array}{l}\text { Lease } \\
\text { Build } \\
\text { Operate } \\
\text { (LBO) }\end{array}$ & $\begin{array}{l}\text { Build } \\
\text { Transfer } \\
\text { Operate } \\
\text { (BTO) }\end{array}$ & $\begin{array}{l}\text { Build } \\
\text { Operate } \\
\text { Transfer } \\
\text { (BOT) }\end{array}$ & $\begin{array}{l}\text { Wraparo } \\
\text { und } \\
\text { Addition }\end{array}$ & $\begin{array}{l}\text { Buy } \\
\text { Build } \\
\text { Operate } \\
\text { (BBO) }\end{array}$ & $\begin{array}{l}\text { Build } \\
\text { Own } \\
\text { Operate } \\
\text { (BOO) }\end{array}$ \\
\hline
\end{tabular}

Fully

Berdasarkan gambar tersebut semakin ke kiri maka peran pemerintah dalam pemanfaatan aset semakin besar. Sedangkan semakin ke kanan maka peran badan usaha yang semakin besar. Adapun keterangan setiap model privatisasi adalah sebagai berikut:

1. Government Departement; the traditional method of providing infrastructure-based services is directly through government departement

2. Public Authority; these are being formed by commercialization (managerial and financial authonomy and separate budgets based on user charges) and corporatization (legal company status with separation of ownership and management).

3. Service Contract; specific services associated with infrastructure may be contracted out to private firms.

4. Operations and Maintenance Contract Lease; a private partner operates and maintains a publicly owned facility under a management contract with the sponsoring government, which owns the facility.

5. Cooperative; non profit, voluntary, cooperative association assumes responsibility for the service.

6. Lease Build Operate (LBO); a private firm is given a long-term lease to develop (with its own funds) and operate an expanded facility. It recovers its investment plus a reasonable return over the term of the lease and pays a rental fee

7. Bulid-Transfer-Operate (BTO); a private developer finances and builds a facility and, upon completion, transfers legal ownership to the sponsoring government agency. The agency then leases the facility back to developer under a long-term lease, during
Fully

which the developer operates the facility and has the opportunity to recover his investment and earn a resonable return from user charges and commercial activities.

8. Build-Operate-Transfer (BTO); a private developer is awarded a franchise (concession) to finance, build, own, and operate a facility (hence this is sometimes referred to as BOOT- build, own, operate, and transfer), and to collect user fees for a specified period, after which ownership of the facility is transferred to the public sector. Similar to BTO but may encounter legal, regulatory, and liability issues arising during the long period of private ownership before the transfer.

9. Wraparound adition; a private developer finances and constructs an addition to an existing public facility, and then operates the combined facility either for a fixed period or until he recovers costs plus a reasonable return on his invested capital. He may on the addition.

10. Buy-Build-Operate (BBO); an existing public facility is sold to a private partner who renovates or expands it and operates it in perpetuity under a franchise. This is equivalent to divesting a company, which then operates under a franchise.

11. Build-Own-Operate (BOO); a private developer finances, builds, owns, and operates a facility in perpetuity under a franchise, subject to regulatory constrains on pricing and operations. The long-term property rights provide a significant financial incentive for capital investment in the facility. 


\section{Pembahasan}

\subsection{Pemanfaatan Aset dan Peningkatan Pendapatan Asli Daerah (PAD)}

Sejak diberlakukannya Undang-Undang Otonomi Daerah, Daerah memiliki kewenangan untuk mengatur dan mengurus urusan pemerintahan dalam sistem Negara Kesatuan Republik Indonesia atau dikenal dengan desentralisasi. Makna dari desentralisasi seperti dikemukakan Duncan (2007:713) ialah a process where central government transfers political, fiscal and administrative powers to lower levels in an administrative and territorial hierarchy. Berdasarkan pengertian tersebut, desentralisasi tidak hanya dimaknai sebagai penyerahan kewenangan secara politik dan administratif tetapi juga penyerahan kewenangan dari sektor fiskal.

Pada dasarnya, desentralisasi fiskal merupakan suatu konsep yang dimaksudkan agar daerah memiliki kewenangan untuk menggali sumber pendapatan asli daerahnya sendiri, mengelola keuangan sendiri dan mempergunalannya sesuai dengan yang telah mereka rencanakan sebelumnya (Soleh, 2010:37) artinya daerah diberikan kewenangan untuk mengelola daerahnya masing-masing sesuai dengan kebutuhan dan potensi daerahnya.

Desentralisasi fiskal juga memberikan kesempatan untuk meningkatkan kesejahteraan ekonomi. Decentralized choice in the public sector (as in the private sector) provides an opportunity to increase economic welfare by tailoring levels of consumption to the preferences of smaller, more homogeneous groups (Oates, 1988:5). Model Tiebout menjelaskan bahwa pilihan desentralisasi di sektor publik adalah untuk meningkatkan efisiensi alokasi sumber daya. Sebagaimana Oates juga mengemukakan bahwa desentralisasi fiskal dilakukan untuk meningkatkan kesejahteraan ekonomi.

Desentralisasi fiskal menuntut daerah agar dapat meningkatkan kreativitas dalam menghimpun pendanaan sehingga dapat membiayai (self financing) pengeluaran daerah sesuai dengan kebutuhannya. Salah satu wujud dari self financing ialah dengan memelihara agar kontribusi pendapatan asli daerah, baik dari sektor pajak daerah, retribusi daerah, dan lainlain pendapatan asli daerah yang sah, menunjukkan tren yang terus meningkat terhadap Pendapatan Daerah.

Upaya yang dilakukan oleh Pemerintah Daerah untuk meningkatkan PADnya banyak menghadapi tantangan Hal ini disebabkan Pendapatan Asli Daerah khususnya pajak daerah dan retribusi daerah cenderung bias ke daerah yang tingkat urbanisasinya tinggi (urban-biased), seperti Pajak Hotel, Pajak Restoran, dan Pajak Kendaraan Bermotor, dan sebagainya. Sehingga untuk daerah yang unsur kekotaannya tidak terlalu tinggi potensi penerimaan pajaknya menjadi kecil.

Salah satu strategi dalam peningkatan PAD yang dapat dilakukan oleh Pemerintah Daerah adalah melalui pemanfaatan aset. Melalui 5 skema dalam pemanfaatan aset ini selain dapat mengoptimalkan aset yang dimiliki, juga dapat meningkatkan kemampuan aset untuk menghasilkan keuntungan melalui beberapa kontribusi sesuai dengan metode pemanfaatan aset. Selain itu melalui pemanfaatan aset dapat menambah nilai aset yang juga dapat menjadi trigger dalam peningkatan PAD khususnya sektor pajak daerah dan retribusi daerah.

Kontribusi merupakan salah satu benefit yang diperoleh dari pemanfaatan Barang Milik Daerah. Terdapat beberapa jenis kontribusi, dimana bentuknya tergantung dengan bentuk pemanfaatan yang dipilih. Adapun jenis kontribusi dalam skema pemanfaatan adalah sebagai berikut:

1. Besaran nilai sewa (apabila pemanfaatan dalam bentuk sewa). Yang dimaksud dengan "formula tarif Sewa" adalah perhitungan nilai Sewa dengan cara mengalikan suatu indeks tertentu dengan nilai Barang Milik Negara/Daerah. Yang dimaksud dengan "besaran Sewa" adalah besaran nilai nominal Sewa Barang Milik Negara/Daerah yang ditentukan.

2. Kontribusi tahunan (apabila pemanfaatan dalam bentuk bangun guna serah/ bangun serah guna) yang besarannya ditetapkan 
berdasarkan hasil perhitungan tim yang dibentuk oleh pejabat yang berwenang.

3. Kontribusi tetap dan pembagian keuntungan (apabila pemanfaatan dalam bentuk kerjasama pemanfaatan). Perhitungan besaran konstribusi pembagian keuntungan yang merupakan bagian Pemerintah Pusat/Daerah harus memperhatikan perbandingan nilai Barang Milik Negara/Daerah yang dijadikan objek Kerja Sama Pemanfaatan dan manfaat lain yang diterima Pemerintah Pusat/Daerah dengan nilai investasi mitra dalam Kerja Sama Pemanfaatan. Besaran kontribusi tetap dan pembagian keuntungan hasil kerja sama pemanfaatan ditetapkan berdasarkan hasil perhitungan tim yang dibentuk dengan Keputusan Kepala Daerah dengan memperhatikan:

a. Nilai tanah dan/atau bangunan sebagai obyek kerjasama ditetapkan sesuai NJOP dan/atau harga pasaran umum, apabila dalam satu lokasi terdapat nilai NJOP dan/atau pasaran umum yang berbeda dilakukan penjumlahan dan dibagi sesuai jumlah yang ada

b. Kegiatan kerjasama pemanfaatan untuk kepentingan umum dan/atau kegiatan perdagangan

c. Besaran investasi dari mitra kerja

d. Penyerapan tenaga kerja dan peningkatan PAD.

4. Pembagian kelebihan keuntungan (apabila pemanfaatan dalam bentuk kerjasama infrastruktur)

Penetapan kontribusi dalam pemanfaatan Barang Milik Negara ditentukan oleh aktivitas penilaian Barang Milik Daerah. Hal ini sesuai dengan amanah Peraturan Pemerintah Nomor 27 Tahun 2014 tentang Pengelolaan Barang Milik Negara/Daerah bahwa penilaian Barang Milik Negara/Daerah dilaksanakan dalam rangka mendapatkan nilai wajar. Penilaian Barang Milik Negara/Daerah dilakukan dalam rangka penyusunan neraca pemerintah, Pemanfaatan dan Pemindahtanganan Barang Milik Negara/ Daerah. Dalam kondisi tertentu, Barang Milik
Negara/Daerah yang telah ditetapkan nilainya dalam neraca Pemerintah Pusat/Pemerintah Daerah, dapat dilakukan Penilaian kembali.

\subsection{Metode dalam Pemanfaatan Barang Milik Daerah (BMD)}

Dalam konteks pemanfaatan aset di Indonesia, beberapa konsep E.S. Savas diadopsi dan dituangkan dalam Peraturan Pemerintah Republik Indonesia Nomor 27 Tahun 2014 tentang Pengelolaan Barang Milik Negara/ Daerah (BMN/D) Pasal 27, bahwa pada dasarnya terdapat 5 metode pemanfaatan BMN/D, yaitu:

\section{Gambar 2 Metode Pemanfaatan Aset}

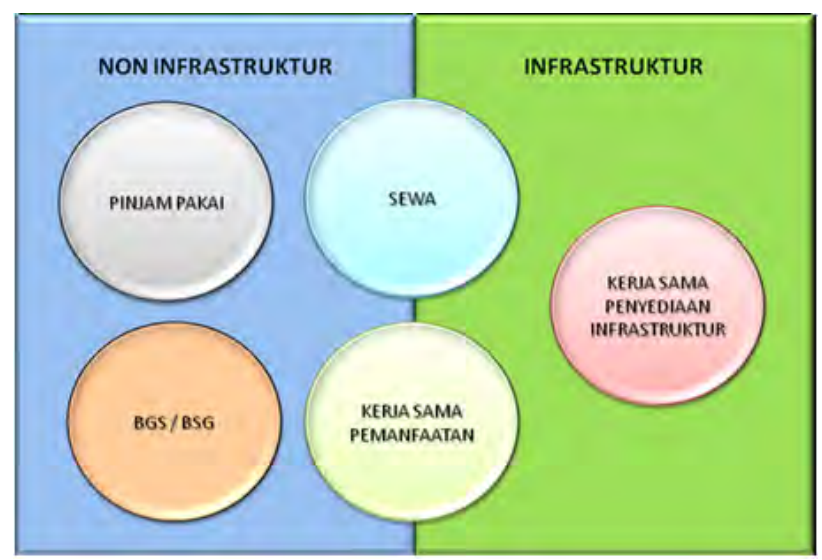

Dalam gambar tersebut nampak bahwa terdapat jenis pemanfaatan pinjam pakai, BGS/BSG, Sewa, Kerja sama pemanfaatan dapat dilakukan atas bentuk pemanfaatan non infrastruktur sedangkan dalam bentuk infrastruktur maka bentuk pemanfaatan yang dapat dipilih adalah sewa, kerja sama pemanfaatan dan kerja sama penyediaan infrastruktur. Adapun ruang lingkup kegiatan infrastruktur berdasarkan Pasal 33 ayat (3) meliputi:

a. infrastruktur transportasi meliputi pelabuhan laut, sungai dan/atau danau, bandar udara, terminal, dan/atau jaringan rel dan/atau stasiun kereta api;

b. infrastruktur jalan meliputi jalan jalur khusus, jalantol, dan/atau jembatan tol;

c. infrastruktur sumber daya air meliputi saluran pembawa air baku dan/atau 
waduk/bendungan;

d. infrastruktur air minum meliputi bangunan pengambilan air baku, jaringan transmisi, jaringan distribusi, dan/atau instalasi pengolahan air minum;

e. infrastruktur air limbah meliputi instalasi pengolah air limbah, jaringan pengumpul dan/atau jaringan utama, dan/atau sarana persampahan yang meliputi pengangkut dan/atau tempat pembuangan;

f. infrastruktur telekomunikasi meliputi jaringan telekomunikasi;

g. infrastruktur ketenagalistrikan meliputi pembangkit, transmisi, distribusi dan/atau instalasi tenaga listrik; dan/atau

h. infrastruktur minyak dan/atau gas bumi meliputi instalasi pengolahan, penyimpanan, pengangkutan, transmisi, dan/atau distribusi minyak dan/atau gas bumi.

$\begin{array}{llll}\text { Berikut akan dijelaskan } & \text { metode } \\ \text { pemanfaatan barang milik daerah } & \text { (BMD) } \\ \text { berdasarkan PP 27 } & \text { Tahun 2014 } & \text { tentang }\end{array}$
pengelolaan BMN/D sebagai berikut:

\subsubsection{Sewa}

Sewa adalah pemanfaatan BMD oleh pihak lain dalam jangka waktu tertentu dan menerima imbalan uang muka tunai. Objek sewa adalah tanah dan/atau bangunan yang sudah diserahkan oleh Pengguna Barang kepada Gubernur/ Bupati/Walikota; Barang Milik Daerah berupa sebagian tanah dan/atau yang masih digunakan oleh pengguna barang; dan BMD selain tanah dan/atau bangunan.

Tujuan sewa adalah optimalisasi BMD yang belum atau tidak dipergunakan dalam pelaksanaan tugas pokok dan fungsi serta mencegah penggunaan oleh pihak lain secara tidak sah. Penyewaan BMD dilakukan sepanjang tidak merugikan daerah dan tidak menganggu pelaksanaan tugas dan fungsi penyelenggaraan pemerintah daerah.

Jangka waktu Sewa paling lama 5 (lima) tahun sejak ditandatanganinya perjanjian. Jangka waktu sewa dapat lebih dari 5 tahun dan dapat diperpanjang untuk: a. Kerja sama infrastruktur;

b. kegiatan dengan karakteristik usaha yang memerlukan waktu sewa lebih dari 5 (lima) tahun, atau;

c. ditentukan dalam undang-undang

Adapun mitra sewa adalah:

a. Pemerintah Daerah dalam hal memanfaatkan BMD tidak untuk penyelenggaraan tugas \& fungsi

b. Badan Usaha Milik Negara/Daerah

c. Swasta

- Perorangan

- Persekutuan Perdata/Firma/Komanditer

- Perseroan Terbatas

- Lembaga/organisasi internasional/

- Yayasan

- Koperasi

d. Unit penunjang kegiatan penyelenggaraan pemerintahan/ negara

- Persatuan/perhimpunan PNS/TNI/POLRI

- Persatuan/perhimpunan istri PNS/TNI/ POLRI

- Unit penunjang kegiatan lainnya

e. Badan Hukum Lainnya

- Bank Indonesia

- Lembaga Penjamin Simpanan

- Badan hukum yang dimiliki negara

- Badan hukum internasional/asing

\subsubsection{Pinjam Pakai}

Pinjam pakai adalah penyerahan penggunaan barang antara Pemerintah Pusat dan Pemerintah Daerah atau antar Pemerintah Daerah dalam jangka waktu tertentu tanpa menerima imbalan dan setelah jangka waktu tersebut berakhir diserahkan kembali kepada Pengelola Barang. Objek pinjam pakai adalah berupa tanah dan/atau bangunan yang sudah diserahkan oleh Pengguna Barang kepada Gubernur/Bupati/ Walikota; Barang Milik Daerah berupa sebagian tanah dan/atau yang masih digunakan oleh pengguna barang; dan BMD selain tanah dan/atau bangunan. Tujuannya adalah optimalisasi BMD yang belum/tidak dipergunakan dalam pelaksanaan tugas pokok dan fungsi juga menunjang penyelenggaraan pemerintah daerah. Jangka waktu pinjam pakai paling lama 5 
tahun dan dapat diperpanjang 1 kali. Dalam hal akan diperpanjang, permintaan perpanjangan diajukan paling lambat 2 bulan sebelum jangka waktu berakhir.

Peminjam pakai dilarang untuk melakukan pemanfaatan atas objek pinjam pakai. Peminjam pakai dapat mengubah BMD sepanjang tidak melakukan perubahan yang mengakibatkan perubahan fungsi dan/atau penurunan nilai BMD dan sepanjang telah mendapat persetujuan dari Pengguna/Pengelola Barang. Pemeliharaan dan biaya yang timbul selama masa pinjam pakai,menjadi tanggung jawab peminjampakai. Setelah masa pinjam pakai berakhir, peminjampakai harus mengembalikan BMD yang dipinjam dalam kondisi sesuai dengan perjanjian.

\subsubsection{Kerja Sama Pemanfaatan}

Kerja sama pemanfaatan adalah pendayagunaan Barang Milik Daerah oleh pihak lain dalam jangka waktu tertentu dalam rangka peningkatan pendapatan daerah dan sumber pembiayaan lainnya. Kerja Sama Pemanfaatan Barang Milik Daerah dengan Pihak Lain dilaksanakan dalam rangka mengoptimalkan daya guna dan hasil guna Barang Milik Daerah; dan/atau meningkatkan pendapatan daerah. Kondisi yang melatarbelakangi kerja sama pemanfaatan adalah tidak tersedia atau tidak cukup tersedia dana dalam Anggaran Pendapatan dan Belanja Daerah untuk memenuhi biaya operasional, pemeliharaan, dan/atau perbaikan yang diperlukan terhadap Barang Milik Daerah tersebut. Objek pinjam pakai adalah berupa tanah dan/atau bangunan yang sudah diserahkan oleh Pengguna Barang kepada Gubernur/Bupati/ Walikota, Barang Milik Daerah berupa sebagian tanah dan/atau yang masih digunakan oleh pengguna barang, dan BMD selain tanah dan/atau bangunan.

Kerja sama pemanfaatan BMD tidak mengubah status BMD. Adapun mitra Kerja Sama Pemanfaatan harus membayar kontribusi tetap setiap tahun selama jangka waktu pengoperasian yang telah ditetapkan dan pembagian keuntungan hasil Kerja Sama Pemanfaatan ke rekening Kas Umum Daerah.
Besaran pembayaran kontribusi tetap dan pembagian keuntungan hasil Kerja Sama Pemanfaatan ditetapkan dari hasil perhitungan tim yang dibentuk oleh:

1. Gubernur/Bupati/Walikota, untuk Barang Milik Daerah berupa tanah dan/atau bangunan;

2. Pengelola Barang Milik Daerah, untuk Barang Milik Daerah selain tanah dan/atau bangunan.

Besaran pembayaran kontribusi tetap dan pembagian keuntungan hasil Kerja Sama Pemanfaatan harus mendapat persetujuan Pengelola Barang.

Dalam Kerja Sama Pemanfaatan Barang Milik Daerah berupa tanah dan/atau bangunan, sebagian kontribusi tetap dan pembagian keuntungannya dapat berupa bangunan beserta fasilitasnya yang dibangun dalam satu kesatuan perencanaan tetapi tidak termasuk sebagai objek Kerja Sama Pemanfaatan. Besaran nilai bangunan beserta fasilitasnya sebagai bagian dari kontribusi tetap dan kontribusi pembagian keuntungan paling banyak $10 \%$ (sepuluh persen) dari total penerimaan kontribusi tetap dan pembagian keuntungan selama masa Kerja Sama Pemanfaatan. Bangunan yang dibangun dengan biaya sebagian kontribusi tetap dan pembagian keuntungan dari awal pengadaannya merupakan Barang Milik Daerah. Dalam hal mitra Kerja Sama Pemanfaatan atas Barang Milik Daerah untuk penyediaan infrastruktur berbentuk Badan Usaha Milik Daerah, kontribusi tetap dan pembagian keuntungan dapat ditetapkan paling tinggi sebesar $70 \%$ (tujuh puluh persen) dari hasil perhitungan tim

Jangka waktu Kerja Sama Pemanfaatan paling lama 30 (tiga puluh) tahun sejak perjanjian ditandatangani dan dapat diperpanjang. Jangka waktu Kerja Sama Pemanfaatan atas Barang Milik Daerah untuk penyediaan infrastruktur dapat diperpanjang paling lama 50 (lima puluh) tahun sejak perjanjian ditandatangani dan dapat diperpanjang. Adapun mitra kerjasama pemanfaatan Badan Umum Milik Negara/Daerah dan pihak swasta kecuali perorangan. Selama jangka waktu pengoperasian, mitra Kerja Sama Pemanfaatan dilarang menjaminkan atau 
menggadaikan Barang Milik Daerah yang menjadi objek Kerja Sama Pemanfaatan. Tanah, gedung, bangunan, sarana dan fasilitas yang dibangun oleh Mitra KSP menjadi BMN sejak diserahkan kepada Pemerintah sesuai perjanjian atau pada saat berakhirnya perjanjian

\subsubsection{Bangun Guna Serah (BGS)/Bangun Serah Guna (BSG)}

Bangun Guna Serah adalah Pemanfaatan Barang Milik Daerah berupa tanah oleh pihak lain dengan cara mendirikan bangunan dan/atau sarana berikut fasilitasnya, kemudian didayagunakan oleh pihak lain tersebut dalam jangka waktu tertentu yang telah disepakati, untuk selanjutnya diserahkan kembali tanah beserta bangunan dan/atau sarana berikut fasilitasnya setelah berakhirnya jangka waktu. Sedangkan Bangun Serah Guna adalah Pemanfaatan Barang Milik Daerah berupa tanah oleh pihak lain dengan cara mendirikan bangunan dan/atau sarana berikut fasilitasnya, dan setelah selesai pembangunannya diserahkan untuk didayagunakan oleh pihak lain tersebut dalam jangka waktu tertentu yang disepakati.

Bangun Guna Serah atau Bangun Serah Guna Barang Milik Negara/Daerah dilaksanakan dengan pertimbangan:

a. Pengguna Barang memerlukan bangunan dan fasilitas bagi penyelenggaraan pemerintahan negara/daerah untuk kepentingan pelayanan umum dalam rangka penyelenggaraan tugas dan fungsi; dan

b. tidak tersedia atau tidak cukup tersedia dana dalam Anggaran Pendapatan dan Belanja Negara/Daerah untuk penyediaan bangunan dan fasilitas tersebut .

Barang Milik Daerah berupa tanah yang status penggunaannya ada pada Pengguna Barang dan telah direncanakan untuk penyelenggaraan tugas dan fungsi Pengguna Barang yang bersangkutan, dapat dilakukan Bangun Guna Serah atau Bangun Serah Guna setelah terlebih dahulu diserahkan kepada:
a. Pengelola Barang, untuk Barang Milik
Negara; atau
b. Gubernur/Bupati/Walikota, untuk Barang

Milik Daerah

Jangka waktu Bangun Guna Serah atau Bangun Serah Guna paling lama 30 (tiga puluh) tahun sejak perjanjian ditandatangani dan tidak dapat diperpanjang. Penetapan mitra Bangun Guna Serah atau mitra Bangun Serah Guna dilaksanakan melalui tender. Adapun mitra BGS/BSG adalah Badan Umum Milik Negara/Daerah, pihak swasta kecuali perorangan, Badan Hukum. Dalam hal mitra BGS/BSG membentuk konsorsium, mitra BGS/BSG harus membentuk badan hukum Indonesia sebagai pihak yang bertindak untuk dan atas nama Mitra BGS/BSG dalam perjanjian BGS/BSG

Mitra Bangun Guna Serah atau mitra Bangun Serah Guna yang telah ditetapkan, selama jangka waktu pengoperasian memiliki kewajiban sebagai berikut:

a. wajib membayar kontribusi ke rekening Kas Umum Negara/Daerah setiap tahun, yang besarannya ditetapkan berdasarkan hasil perhitungan tim yang dibentuk oleh pejabat yang berwenang;

b. wajib memelihara objek Bangun Guna Serah atau Bangun Serah Guna; dan

c. dilarang menjaminkan, menggadaikan, atau memindahtangankan:

1. tanah yang menjadi objek Bangun Guna Serah atau Bangun Serah Guna;

2. hasil Bangun Guna Serah yang digunakan langsung untuk penyelenggaraan tugas dan fungsi Pemerintah Pusat/Daerah; dan/atau

3. hasil Bangun Serah Guna.

Dalam jangka waktu pengoperasian, hasil Bangun Guna Serah atau Bangun Serah Guna harus digunakan langsung untuk penyelenggaraan tugas dan fungsi Pemerintah Pusat/ Daerah paling sedikit 10\% (sepuluh persen).

Mitra Bangun Guna Serah Barang Milik Daerah harus menyerahkan objek Bangun Guna Serah kepada Gubernur/Bupati/Walikota pada akhir jangka waktu pengoperasian, setelah dilakukan audit oleh aparat pengawasan intern Pemerintah dengan tata cara sebagai berikut:

a. mitra Bangun Serah Guna harus menyerahkan objek Bangun Serah Guna kepada 
Gubernur/Bupati/ Walikota setelah selesainya pembangunan;

b. hasil Bangun Serah Guna yang diserahkan kepada Gubernur/Bupati/Walikota ditetapkan sebagai Barang Milik Daerah;

c. mitra Bangun Serah Guna dapat mendayagunakan Barang Milik Daerah sebagaimana dimaksud pada huruf b sesuai jangka waktu yang ditetapkan dalam perjanjian; dan

d. setelah jangka waktu pendayagunaan berakhir, objek Bangun Serah Guna terlebih dahulu diaudit oleh aparat pengawasan intern Pemerintah sebelum penggunaannya ditetapkan oleh Gubernur/Bupati/ Walikota.

\subsubsection{Kerja Sama Penyediaan Infrastruktur}

Kerja sama penyediaan infrastruktur adalah kerja sama antara Pemerintah dan Badan Usaha untuk kegiatan penyediaan infrastruktur sesuai dengan ketentuan Peraturan Perundangundangan. Kerja Sama Penyediaan Infrastruktur atas Barang Milik Negara/Daerah dilaksanakan terhadap:

a. Barang Milik Daerah berupa tanah dan/atau bangunan pada Pengelola Barang/Pengguna Barang;

b. Barang Milik Daerah berupa sebagian tanah dan/atau bangunan yang masih digunakan oleh Pengguna Barang; atau

c. Barang Milik Daerah selain tanah dan/atau bangunan.

Kerja Sama Penyediaan Infrastruktur atas Barang Milik Negara/Daerah dilakukan antara Pemerintah dan Badan Usaha. Badan Usaha sebagaimana dimaksud adalah badan usaha yang berbentuk:

a. perseroan terbatas;

b. Badan Usaha Milik Negara;

c. Badan Usaha Milik Daerah; dan/atau

d. koperasi

Jangka waktu Kerja Sama Penyediaan Infrastruktur paling lama 50 (lima puluh) tahun dan dapat diperpanjang. Penetapan mitra Kerja Sama Penyediaan Infrastruktur dilaksanakan sesuai ketentuan peraturan perundang-undangan. Mitra Kerja Sama Penyediaan Infrastruktur yang telah ditetapkan, selama jangka waktu Kerja
Sama Penyediaan Infrastruktur:

a. dilarang menjaminkan, menggadaikan, atau memindahtangankan Barang Milik Negara/ Daerah yang menjadi objek Kerja Sama Penyediaan Infrastruktur;

b. wajib memelihara objek Kerja Sama Penyediaan Infrastruktur dan barang hasil Kerja Sama Penyediaan Infrastruktur; dan

c. dapat dibebankan pembagian kelebihan keuntungan sepanjang terdapat kelebihan keuntungan yang diperoleh dari yang ditentukan pada saat perjanjian dimulai (clawback).

Pembagian kelebihan keuntungan disetorkan ke Kas Umum Negara/Daerah dengan formula dan/atau besaran pembagian kelebihan keuntungan ditetapkan oleh:

a. Pengelola Barang, untuk Barang Milik Negara; atau

b. Gubernur/Bupati/Walikota, untuk Barang Milik Daerah.

Mitra Kerja Sama Penyediaan Infrastruktur harus menyerahkan objek Kerja Sama Penyediaan Infrastruktur dan barang hasil Kerja Sama Penyediaan Infrastruktur kepada Pemerintah pada saat berakhirnya jangka waktu Kerja Sama Penyediaan Infrastruktur sesuai perjanjian. Barang hasil Kerja Sama Penyediaan Infrastruktur menjadi Barang Milik Negara/Daerah sejak diserahkan kepada Pemerintah sesuai perjanjian.

\subsection{Studi Kasus Pemilihan Metode Pe- manfaatan Barang Milik Daerah dalam Pengembangan Kawasan Pariwisata Pantai X}

Pengembangan kawasan wisata di era otonomi daerah menjadi salah satu potensi dalam peningkatan Pendapatan Asli Daerah (PAD). Hal ini disebabkan Pendapatan Asli Daerah khususnya Pajak Daerah dan Retribusi Daerah cenderung bias ke daerah yang tingkat urbanisasinya tinggi (urban-biased), seperti Pajak Hotel, Pajak Restoran, dan Pajak Kendaraan Bermotor. Sehingga untuk daerah yang unsur kekotaannya tidak terlalu tinggi potensi penerimaan pajaknya menjadi kecil. Dengan 
adanya fakta tersebut, maka salah satu sektor strategis yang dapat dijadikan trigger peningkatan PAD adalah sektor pariwisata. Pengembangan sektor pariwisata harus mampu mendatangkan wisatawan baik dalam dan luar negeri yang potensial.Wisatawan yang tidak sekedar mengunjungi pantai dan berlalu begitu saja tetapi wisatawan yang keberadaannya dapat menguntungkan perekonomian masyarakat setempat.Wisatawan tertarik untuk menginap dilokasi setempat, makan di restoran setempat, membeli aneka souvenir hasil masyarakat setempat.

Berikut akan dibahas studi kasus pemilihan metode pemanfaatan BMD pada kawasan wisata Pantai X di Kabupaten Y. Pada saat dilakukan penelitian, terdapat sejumlah permasalahan yang ditemui dalam pengelolaan kawasan pantai salah satunya akses jalan menuju Pantai X masih dimiliki masyarakat. Masyarakat yang membangun jalan menuju ke pantai merasa memiliki jalan tersebut sehingga setiap wisatawan yang masuk dipungut uang masuk ke kawasan Pantai $\mathrm{X}$. Akibat dari kondisi ini adalah terjadi potential lost dari sektor retribusi tempat rekreasi dan oleh raga. Sesungguhnya pemerintah daerah dapat memanfaatkan kondisi ini namun terdapat beberapa persyaratan yang harus dipenuhi agar pemerintah daerah dapat mengambil manfaat khususnya dari sektor retribusi tempat rekreasi dan olah raga. Pemerintah Kabupaten Y harus membangun sarana dan prasarana yang memadai sehingga menjadi legitimasi untuk memungut retribusi. Pemerintah dapat mengoptimalkan aset kawasan wisata tersebut perlu membuka akses jalan menuju pantai.

Pengadaan sarana dan prasarana dalam mengembangkan sektor pariwisata bisa dilakukan melalui dua cara yaitu pengadaan dengan pendanaan sendiri atau pengadaan yang melibatkan pihak ke-3 yang secara teoritis dikenal dengan istilah public and private partnership. Mekanisme ini kemudian dalam Peraturan Pemerintah Nomor 27 Tahun 2014 dikenal dengan istilah pemanfaatan.

Berdasarkan hasil wawancara diketahui bahwa tujuan pemanfaatan Kawasan Wisata Pantai X yaitu kawasan perhotelan bertaraf internasional maka bentuk pemanfaatan termasuk pada bentuk pemanfaatan noninfrastruktur. Berdasarkan hasil wawancara diketahui bahwa pihak ketiga yang melakukan pemanfaatan adalah pihak swasta. Dengan demikian maka model pemanfaatan yang memungkinkan adalah sewa, bangun guna serah/bangun serah guna, dan kerja sama pemanfaatan.

Jika dilihat dari sisi jangka waktu pemanfaatan maka bentuk kerja sama sewa memiliki kelemahan sebab jangka waktu pemanfaatan paling lama 5 tahun dan dapat diperpanjang jika memenuhi 3 syarat:

1. Kerja sama infrastruktur

2. Kegiatan dengan karakteristik usaha yang memerlukan waktu sewa lebih dari 5 tahun, atau

3. Ditentukan lain dengan undang-undang.

Mengacu pada ketentuan tersebut, bentuk pemanfaatan sewa dianggap kurang sesuai mengingat jangka waktu pemanfaatan yang relatif singkat menimbulkan resiko keamanan investasi bagi pihak investor. Jangka waktu pemanfaatan yang akan dievaluasi setiap 5 tahun sekali memberikan potensi ketidakpastian investasi perhotelan pada kawasan tersebut

Berdasarkan pertimbangan tersebut maka bentuk pemanfaatan yang paling memungkinkan adalah Bangun Guna Serah/Bangun Serah Guna dan Kerja Sama Pemanfaatan. Adapun pemilihan bentuk kerja sama akan sangat tergantung dengan dasar pertimbangan Pemerintah Daerah Kabupaten Y. Dasar dari kerja sama pemanfaatan Barang Milik Daerah (BMD) dalam rangka mengoptimalkan daya guna dan hasil guna BMD dan meningkatkan penerimaan daerah. Adapun dasar pertimbangan Bangun Guna Serah/Bangun Serah Guna adalah pengguna barang memerlukan bangunan dan fasilitas bagi penyelenggaraan pemerintahan negara/daerah untuk kepentingan pelayanan umum dalam rangka penyelenggaraan tugas dan fungsi dan tidak tersedia atau tidak cukup tersedia dana dalam APBD untuk penyediaan bangunan dan fasilitas tersebut. Dasar pertimbangan penyelenggaraan pemanfaatan menimbulkan konsekuensi yang berbeda baik dalam hal jangka waktu dan jenis 
kontribusi.

Pemilihan bentuk pemanfaatan harus didasarkan pada visi dan misi kepariwisataan pemerintah daerah serta mampu menimbulkan efek rentetan (multiplier effect) terhadap perekonomian masyarakat. Untuk itu terdapat dua model kebijakan pemanfaatan yang dapat diajukan:

\section{Model Bangun Guna Serah atau Bangun Serah Guna (BGS/BSG)}

\section{a. Motif Pemanfaatan dengan Bentuk Bangun Guna Serah atau Bangun Serah Guna}

Model pemanfaatan BGS/BSG dipersyaratkan ketika pengguna barang memerlukan bangunan dan fasilitas bagi penyelenggaraan pemerintahan negara/daerah untuk kepentingan pelayanan umum dalam rangka penyelenggaraan tugas dan fungsi dan tidak tersedia atau tidak cukup tersedia dana dalam APBD untuk penyediaan bangunan dan fasilitas tersebut. Berdasarkan hal tersebut, jika Pemerintah Kabupaten $\mathrm{Y}$ memerlukan bangunan dan fasilitas untuk penyelenggaraan tugas pokok dan fungsi maka pemanfaatan Kawasan Wisata Pantai X dapat berupa menggunakan mekanisme BSG/BGS. Adapun pihak yang dapat menjadi mitra BGS/BSG adalah BUMN/D, Swasta (kecuali perorangan).

\section{b. Perbedaan Bangun Guna Serah dan Bangun Serah Guna}

Pada dasarnya BGS adalah pemanfaatan tanah pemerintah pusat oleh pihak lain dengan mendirikan bangunan dan/atau sarana berikut fasilitasnya, kemudian didayagunakan oleh pihak lain tersebut dalam jangka tertentu yang telah disepakati dan selanjutnya diserahkan kembali kepada Pengelola Barang setelah jangka waktu berakhir. Sedangkan BSG adalah pemanfaatan tanah milik pemerintah pusat oleh pihak lain dengan mendirikan bangunan dan/atau sarana berikut fasilitasnya, kemudian diserahkan kepada Pengelola Barang untuk kemudian didayagunakan oleh pihak lain tersebut dalam jangka yang telah disepakati. Perbedaan yang mendasar antara BGS dan BSG terkait dengan sistem audit.Pada BSG audit dilakukan di awal sebelum dioperasikan. Keuntungannya Pemerintah Darah dapat mengetahui nilai bangunan sehingga memiliki legitimasi hukum yang tinggi. Mitra BSG berkewajiban untuk menyerahkan bangunan hasil BSG ketika kontrak berakhir dengan nilai bangunan yang sesuai dengan audit di awal. Sedangkan pada BGS audit dilakukan di akhir. Sistem BGS memiliki kelemahan terkait dengan willingness dalam pemeliharaan bangunan.

Beberapa fakta empiris menunjukan bahwa BSG lebih efektif dari pada BGS. Salah satu studi penelitian yang dilakukan melalui kajian benchmarking dengan Pemerintah Kabupaten Kepulauan Seribu bentuk pemanfaatan lebih difokuskan kepada BSG hal ini disebabkan berdasarkan pengalaman kerja sama pemanfaatan yang terjadi selama ini bahwa kondisi bangunan pada akhir masa kontrak tidak terpelihara. Atas pertimbangan itulah, saat ini bentuk pemanfaatan pada Pemerintah Kabupaten Kepulauan Seribu diarahkan kepada model Bangun Serah Guna (BSG).

Fakta Kedua terkait dengan pengalaman Pemerintah Kabupaten $\mathrm{Y}$ atas Pengelolaan Pantai $\mathrm{Z}$ yang menggunakan mekanisme BGS dimana terjadinya permasalahan pada saat penyerahan bangunan kepada pemerintah daerah setelah berakhirnya masa kontrak. Mekanisme BGS memberikan efek lain dimana pihak ketiga merasa memiliki bangunan tersebut setelah 30 tahun memanfaatkan aset daerah tanpa melakukan audit aset diawal pembangunan. Atas beberapa fakta tersebut maka jika Pemerintah Daerah Kabupaten Y hendak memilih model ini dalam melakukan pemanfaatan Kawasan Pantai $X$, maka seyogyanya menggunakan mekanisme Bangun Serah Guna (BSG).

\section{c. Keunggulan Model Bangun Guna Serah dan Bangun Serah Guna}

1) Keamanan Aset Terjaga

Keamanan aset menggunakan model BGS/BSG lebih tinggi dibandingkan dengan 
kerjasama pemanfaatan disebabkan oleh beberapa hal:

- Pasal 36 ayat (1) bahwa jangka waktu BGS/BSG paling lama 30 tahun sejak perjanjian ditandatangani. Jangka waktu yang ditetapkan paling lama 30 tahun merupakan sebuah konsekuensi jika mengacu kepada motif pemanfaatan menggunakan mekanisme BSG/BGS. Pada dasarnya mekanisme ini ditujukan ketika pemerintah daerah memerlukan aset dalam penyelenggaraan tugas pokok dan fungsi namun tidak memiliki cukup dana. Oleh karena itulah, sifat dasar jangka waktu pemanfaatan aset dibatasi agar sesegera mungkin dapat digunakan dalam penyelenggaraan tugas pokok dan fungsi.

- Pasal 36 ayat (3) huruf b dan c, bahwa Mitra BGS/BSG selama jangka waktu pengoperasian 1) wajib memelihara objek BGS/BSG dan 2) dilarang menjaminkan, menggadaikan, atau memindahtangankan tanah yang menjadi objek BGS/BSG; hasil BGS yangdigunakan langsung untuk penyelenggaraan tugas dan fungsi Pemerintah Daerah, dan hasil Bangu Serah Guna.

- Pasal 36 ayat (6) bahwa "Izin mendirikan bangunan dalam rangka Bangun Guna Serah atau Bangun Serah Guna harus diatas namakan Pemerintah Daerah untuk Barang Milik Daerah". Kondisi ini mengandung keunggulan juga kelemahan. Keunggulannya bahwa pemerintah daerah memiliki legitimasi hukum dalam perijinan mendirikan bangun melalui mekanisme BGS/BSG. Atas keunggulan tersebut pemerintah perlu mengalokasikan sejumlah dana untuk membiayai kepengurusan perijinan tersebut.

\section{2) Sifat Kontribusi}

- Mekanisme ini mewajibkan pihak ketiga membayar kontribusi ke Rekening Kas Umum Daerah setiap tahunnya yang besarannya ditetapkan berdasarkan hasil perhitungan tim yang dibentuk oleh pejabat yang berwenang.
- Terdapat keuntungan lain dari model BGS/BSG dimana 10\% hasil Bangun Guna Serah atau Bangun Serah Guna harus digunakan langsung untuk penyelenggaraan tugas dan fungsi Pemerintah Pusat/Daerah paling sedikit 10\% (sepuluh persen). Klausul ini memberi ruang bagi pemerintah daerah mendapatkan bangunan di awal masa pembangunan. Jika pemanfaatan kawasan wisata pantai, maka bangunan tersebut dapat diperuntukan bagi SKPD yang terkait dengan pengembangan wisata atau SKPD lain yang berfungsi menunjang pemngembangan sektor pariwisata, misalnya Dinas Koperasi, UMKM, dan sebagainya. Besarnya bagian objek BGS/BSG yang digunakan untuk tugas dan fungsi ditetapkan oleh Pengelola Barang/ Pengguna Barang.

\section{Model Kerja Sama Pemanfaatan}

\section{a. Motif Pemanfaatan Kerja Sama Pemanfaatan}

Model Kerja Sama Pemanfaatan dapat digunakan jika objeknya berupa tanah/bangunan, sebagian tanah/bangunan dan selain tanah/ bangunan. Terkait dengan ruang lingkup objek pemanfaatan, model kerja sama pemanfaatan lebih fleksibel dari pada BGS/BSG sebab mencakup objek selain tanah dan bangunan. Model kerja sama memiliki keunggulan dari sisi Jangka waktu kerjasama pemanfaatan paling lama 30 (tiga puluh) tahun sejak ditandatanganinya perjanjian KSP dan dapat diperpanjang.

\section{b. Karakteristik dari model kerja sama pemanfaatan}

Karakteristik kerja sama pemanfaatan adalah sebagai berikut:

b. Tanah, gedung, bangunan, sarana, dan fasilitas yang dibangun oleh mitra KSP menjadi BMD sejak diserahkan kepada pemerintah sesuai dengan perjanjian atau pada saat berakhirnya perjanjian

c. Biaya persiapan KSP yang dikeluarkan 
oleh Pengelola Barang atau Pengguna Barang s.d. Penunjukan Mitra KSP dibebankan pada APBD

d. Biaya persiapan KSP yang terjadi setelah ditetapkannya Mitra KSP dibebankan pada mitra KSP dan tidak diperhitungkan dalam pembagian keuntungan

e. Mitra KSP ditentukan melalui tender, kecuali BMD yang bersifat khusus

f. Pihak yang dapat menjadi mitra adalah BUMD dan Swasta kecuali perorangan

\section{c. Jenis kontribusi adalah:}

Terdapat dua jenis kontribusi, yaitu

- Kontribusi tetap

Perhitungan kontribusi tetap $=$ Besaran persentase kontribusi tetap $\mathrm{x}$ nilai wajar objek KSP

- Pembagian keuntungan hasil pendapatan KSP

Perhitungan pembagian keuntungan = Perhitungan Pembagian Keuntungan $\mathrm{x}$ Besaran Keuntungan Pelaksanaan KSP

Kontribusi dapat berbentuk bangunan

- Kerja Sama Pemanfaatan Barang Milik Negara/Daerah berupa tanah dan/atau bangunan, sebagian kontribusi tetap dan pembagian keuntungannya dapat berupa bangunan beserta fasilitasnya yang dibangun dalam satu kesatuan perencanaan tetapi tidak termasuk sebagai objek Kerja Sama Pemanfaatan

- Besaran nilai bangunan beserta fasilitasnya sebagai bagian dari kontribusi tetap dan kontribusi pembagian keuntungan paling banyak $10 \%$ (sepuluh persen) dari total penerimaan kontribusi tetap dan pembagian keuntungan selama masa Kerja Sama Pemanfaatan bangunan yang dibangun dengan biaya sebagian kontribusi tetap dan pembagian keuntungan dari awal pengadaannya merupakan Barang Milik Negara/Daerah.

Kontribusi dalam bentuk bangunan dapat diperuntukan bagi pembangunan sarana dan prasarana fasilitas publik dan tidak terikat pada pembangunan dalam rangka menunjang tugas pokok dan fungsi SKPD tertentu sebagaimana yang dipersyaratkan dalam BGS dan BSG

Pada akhirnya baik BGS/BSG ataupun Kerja Sama Pemanfaatan akan diserahkan kepada daerah pada akhir masa kontrak. Setiap bentuk kerja sama memiliki sisi keuntungan dan kelemahannya dan bersifat trade off sehingga pemilihan model sangat tergantung pada motif pemerintah daerah dalam pengembangan wisata. Jika urgensinya terletak pada penambahan fasilitas untuk penyelenggaraan tupoksi namun Pemda belum memiliki dana yang cukup maka bentuk pemanfaatkan dapat diarahkan kepada BGS/BSG. Namun jika urgensinya terletak pada peningkatan PAD maka bentuk pemanfaatan dapat diarahkan kepada kerja sama pemanfaatan.

Pada prinsipnya, pembangunan wilayah harus menjadi stimulus bagi masyarakat untuk meningkatkan perekonomian di wilayah Kabupaten Y. Dengan adanya pengembangan sektor wisata ini diharapkan akan memberikan trickle down effect terhadap peningkatan PAD. Peran pemerintah selain sebagai regulator juga berperan sebagai stimulator. Dana yang dimiliki pemerintah daerah dapat digunakan sebagai stimulan untuk mengarahkan investasi swasta/ masyarakat ke arah yang diinginkan oleh pemerintah daerah. Untuk menarik wisatawan mengunjungi Kabupaten $\mathrm{Y}$ dapat dilakukan melalui beberapa aspek seperti sektor pariwisata, kebudayaan, serta industri kreatif.

\section{Kesimpulan dan Saran}

Pemanfaatan Barang Milik Daerah (BMD) adalah pendayagunaan BMD yang tidak digunakan untuk penyelenggaraan tugas dan fungsi satuan kerja perangkat daerah dan/atau optimalisasi Barang Milik Daerah dengan tidak mengubah status kepemilikannya. Pemanfaatan BMD memberikan peluang bagi daerah untuk meningkatkan PADnya serta meningkatkan fasilitas publik. Terdapat jenis pemanfaatan pinjam pakai, BGS/BSG, Sewa, Kerja sama pemanfaatan yang dapat dilakukan atas bentuk pemanfaatan non infrastruktur sedangkan dalam bentuk infrastruktur maka bentuk pemanfaatan yang dapat dipilih adalah sewa, kerja sama 
pemanfaatan dan kerja sama penyediaan infrastruktur. Dalam rangka peningkatan pendapatan asli daerah, setiap metode pemanfaatan aset (kecuali pinjam pakai) memiliki bentuk kontribusinya masing-masing yang mampu meningkatkan pendapatan daerah dan atau peningkatan aset daerah.

Setiap bentuk kerja sama memiliki sisi keuntungan dan kelemahannya dan bersifat trade off sehingga pemilihan model sangat tergantung pada motif pemerintah daerah dalam pengembangan wisata. Jika urgensinya terletak pada penambahan fasilitas untuk penyelenggaraan tupoksi namun Pemda belum memiliki dana yang cukup maka bentuk pemanfaatkan dapat diarahkan kepada BGS/BSG. Namun jika urgensinya terletak pada peningkatan PAD maka bentuk pemanfaatan dapat diarahkan kepada kerja sama pemanfaatan. Selain itu, Pemilihan metode pemanfaatan aset hendaknya didasarkan pada visi dan misi daerah serta metode yang paling memberikan dampak rentetan terbesar terhadap pertumbuhan ekonomi daerah.

\section{DAFTAR PUSTAKA}

Duncan CR. 2007. Mixed outcomes: The impact of regional autonomy and decentralization on indigenous ethnic minorities in Indonesia. Dev. Change

Oates, Wallace E \& John Joseph Wallis. 1988. Decentralization in the Public Sector: An Empirical Study of State and Local Government. Chicago: University of Chicago Press

Oates, William E. 2005. Toward a Second Generation Theory of Fiscal Federalism. International Tax and Public Finance

Savas, E. S. 2000. Privatization and Public Private Partnership. London: Chantam House Publisher

Siregar, Doli D. 2004. Manajemen Aset. Jakarta: Gramedia
Soleh, Chabib dan Heru Rochmansjah. 2010. Pengelolaan Keuangan dan Aset Daerah. Bandung: Fokus Media

Undang-Undang Nomor 28 Tahun 2009 tentang Pajak Daerah dan Retribusi Daerah

Undang-Undang Nomor 23 Tahun 2014 tentang Pemerintahan Daerah

Peraturan Pemerintah Republik Indonesia Nomor 27 Tahun 2014 tentang Pengelolaan Barang Milik Negara/Daerah

Peraturan Menteri Keuangan Republik Indonesia Nomor 78/PMK.06/2014 tentang Tata Cara Pelaksanaan Pemanfaatan Barang Milik Negara

Peraturan Menteri Dalam Negeri Nomor 19 Tahun 2016 tentang Pedoman Pengelolaan Barang Milik Daerah 